\title{
Faecal Contaminants in Edible Bivalves from Maputo Bay, Mozambique: Seasonal Distribution, Pathogenesis and Antibiotic Resistance
}

\author{
Betty Collin ${ }^{1,2}$, Ann-Sofi Rehnstam-Holm ${ }^{1,2}$ and Bodil Hernroth ${ }^{*, 3}$
}

\author{
${ }^{1}$ Department of Biomedicine, Göteborg University, Guldhedsgatan 10, 41346 Göteborg; ${ }^{2}$ Department of Mathematics \\ and Natural Sciences, Kristianstad University, 29188 Kristianstad; ${ }^{3}$ The Royal Swedish Academy of Sciences, Kristine- \\ berg 566, 45034 Fiskebäckskil, Sweden
}

\begin{abstract}
In Maputo, Mozambique marine bivalves considerably contribute to the diet of the population. This study aimed to investigate seasonal distribution of Escherichia coli and Salmonella in clams from Maputo Bay, and examine their pathogenesis and antibiotic-resistant patterns. Standard multiple tube method revealed that the concentration of coliforms in all samples exceeded the limit for direct consumption, according to EU standards. Thirty-eight percent of the samples contained $>60,000$ MPN per 100 gram flesh. The occurrence of $E$. coli did not differ significantly due to season, while Salmonella was present in $100 \%$ of the samples during the rainy period and only in $30 \%$ during the dry. Multiplex polymerase chain reaction showed that $45 \%$ of $E$. coli isolates were positive for the virulent indicator gene fimA. The Salmonella isolates were identified as $S$. enterica serovar Typhimurium. Among other isolated coliformic Enterobacteriaceae, Shigella sp. (specie), which in low doses can cause severe gastrointestinal infections, was identified. Antimicrobial susceptibility, recorded by the disk diffusion method, showed resistance to the most commonly used antibiotics. This high levels of faecal contaminants in the clams points out the need for risk assessment and sanitary improvements.
\end{abstract}

\section{INTRODUCTION}

Marine bivalve mollusks, like oysters, mussels and clams, are globally important food resources. They are particularly important in developing countries; mostly because they are easily collected in shallow areas and have high nutritional value. These species are sedentary and filter-feeding which favor bioaccumulation of microorganisms, which make them frequently involved in outbreaks of gastroenteritis [1-3]. Investigations of shell middens testify that the exploitation of bivalves by man has increased enormously over recent decades in southern Africa [4]. Maputo Bay in southern Mozambique is a sheltered area where people regularly collect clams from the intertidal flats and shellfish contributes considerably to the diet of the population [5]. The water is highly contaminated by shipping and untreated sewage from point and non-point sources of Maputo City and from the rivers entering the Bay. Despite this fact the sanitary safety of shellfish has been neglected, with only a few studies on human enteric pathogens. In 1993 Fernandes et al. [6] reported Salmonella spp. (specie plurium) and Vibrio spp. and in 2006, Nenonen et al. [7] detected a high prevalence of Hepatitis A in clams from Maputo, indicating that bivalves in the region can be a significant vector of both enteric bacteria and viruses.

In developing countries diarrhea diseases are common among all age groups and constitute one of the main health problems [8]. Beside malaria and tuberculosis, diarrhea is registered as the principal infectious disease in Maputo [9]. In addition, it is the main cause of illness in travelers from industrialized countries to the developing world $[10,11]$.

*Address correspondence to this author at the Royal Swedish Academy of Sciences, Kristineberg 566, 45034 Fiskebäckskil, Sweden; Tel: +46 523 18513; Fax: +46 523 18502; E-mail: bodil.hernroth@marecol.gu.se
Due to poor sanitary conditions there are certainly several emerging sources for transmission of pathogens to humans, such as contaminated drinking water. However, the rapid economic development and population growth have without doubt increased which raise the pollution of the coastal water. Thus the high consumption of bivalves harvested in the Bay might contribute to transmission of pathogens causing gastroenteritis and be of significance for public health.

Escherichia coli is frequently used as an indicator organism for fecal contamination in food and water. This species is in most cases quite harmless but some strains are highly pathogenic to humans. Especially in infants in developing countries the enteropathogenic E. coli (EPEC) and the enterotoxigenic E. coli (ETEC) are commonly implicated in diarrhea $[12,13]$. Contrary to E. coli, Salmonella spp. are in general pathogenic to humans and represents one of the main causes of food borne illness worldwide [14]. Sea food in particular has been recognized as potential vectors [15-17]. Multi-drug resistance among non-typhoidal Salmonellae (NTS) tends to increase in Eastern Africa [18] and if spread in the marine environment it can contribute to health problems. In order to initiate risk assessment for bivalve consumption the aim of this study was to investigate seasonal distribution of E. coli and Salmonella in clams from Maputo, and examine their pathogenesis and antibiotic-resistant patterns.

\section{MATERIAL AND METHODS}

\section{Area Description, Sample Collection and Preparation}

Maputo Bay, in southern Mozambique (Fig. 1) is a semienclosed bay which opens into the Indian Ocean in the northeast.

The capital, Maputo, with approximately two million residents, is situated on the western side of the bay where the 
rivers Umbeluzi, Tembe and Matola enter the harbor. Another two rivers drain into the bay, the Incomati River in the northern end and Maputo River in the south-west. The highest flows are recorded in these two rivers, which supply the bay with a yearly mean of $200-300 \mathrm{~m}^{3}$ per sec of freshwater [19]. The tide of the area is semi-diurnal with a range at spring of about $3 \mathrm{~m}$ and the residence time for the water of the bay versus oceanic water is approximately two weeks. Southern Mozambique belongs to the sub tropical zone characterized by two seasons; a warm and rainy (October-March) and a colder and dry (April-September). In order to investigate seasonality in the occurrence of the pathogens the sampling was carried out in May-June 2004 and in November 2005. Clams of the two most abundant edible species, Meretrix meretrix and Eumarcia paupercula, were bought from collectors at two popular gathering sites; Bairro dos Pescadores in the north eastern part of the bay and Bairro Luis Cabral in the inner part, close to the harbor. Clams were also bought from three different fish markets along the coastline of the bay (Central market, Marítimo and Costa do Sol). In total 34 samples were collected. Twenty-two of them were dispersed over a period of five weeks during the dry season and 12 samples were dispersed over two weeks during the rainy season. After purchase, the clams were placed in plastic bags and directly transported to the laboratory. Analyses started within one hour. Damaged or open clams were discarded and the remaining clams were opened with a flame sterilized shucking knife. Ten to 20 individuals of $M$. meretrix or E. paupercula, given a total weight of 50-70 grams, were used for each analysis.

\section{Total Coliforms and E. coli}

Clam tissue was homogenized in $2 \mathrm{ml} 0.1 \%$ peptone buffer (pH 7.2; Merck, Darmstadt, Germany) per gram. Most probable number (MPN per $100 \mathrm{~g}$ soft tissue) of coliforms was determined using the standard multiple tube method [20] with 5 replicates; 4 dilutions each, in Mineral Modified Glutamate Broth [1000 ml: 11.4g Minerals Modified Medium Base (Oxoid LTD., Basingstoke, Hampshire, England); 6.4g
Sodium Glutamate (Oxoid), and 5g Ammonium Chloride]. The tubes were incubated at $37 \pm 2^{\circ} \mathrm{C}$ for $24 \pm 2 \mathrm{~h}$. One $\mu \mathrm{l}$ from each positive tube was recultivated onto Tryptone Bile Glucuronide Agar (Chromocult ${ }^{\circledR}$ TBX, CM 0945 A; Oxoid) plates and incubated at $44 \pm 1^{\circ} \mathrm{C}$ for $22 \pm 2 \mathrm{~h}$. From each sample two to five colonies that were morphologically judged as E. coli, were isolated and transported in Liquid Media Transport Swabs tubes (COPAN Italia S.p.a., Brescia Italy) to Kristianstad University, Sweden, for identification, virulence screening and antibiotic resistance tests. API-20E (bioMerieux Inc., Hazelwood, MO) was used for the identification of the E. coli isolates. The isolates were added to twenty pre-treated mini-test tubes in accordance to the manufactures' instructions and incubated at $37^{\circ} \mathrm{C}$ for $20 \pm 2 \mathrm{~h}$. The biochemical characteristics were evaluated with the software provided by bioMerieux Inc.

The identified $E$. coli isolates were screened for presence of the virulence genes iut, fimA, sfaD, papC, hlyA, eaeA, $V T 1, V T 2$, perA, LT, ST, pet, astA and aggR (Table 1) using Multiplex PCR [21]. Briefly, $0.5 \mu 1$ of each of the primers and one bacterial colony were added to $25 \mu$ l Master Mix (HotStarTaq Master Mix, Qiagen,) and sterile $\mathrm{H}_{2} \mathrm{O}$ was added to adjust the final volume to $50 \mu \mathrm{l}$. The PCR amplification was performed according to Table 1 . PCR products were run on gel electrophoresis $(80 \mathrm{~V}, 30-60 \mathrm{~min})$ using DNA ladder GeneRulerTM $100 \mathrm{bp}$ as size standard and examined under UV-light illumination.

\section{Salmonella spp.}

The presence of Salmonella spp. was determined by standard method NMKL nr71 from the Nordic Committee on Food Analysis [22]. Homogenized clam tissue (25 g) was pre-enriched in $225 \mathrm{ml} 0.1 \%$ peptone buffer at $37^{\circ} \mathrm{C}$ for $18 \mathrm{~h}$. Subsequently $100 \mu \mathrm{l}$ were transferred to each of five tubes containing pre-warmed Rappaport-Vassiliadis Soy Peptone Broth (CM0866, Oxoid). The tubes were incubated at $41.5 \pm 0.5^{\circ} \mathrm{C}$ for $24 \pm 3 \mathrm{~h}$. One $\mu \mathrm{l}$ of the enrichment was spread onto five replicates of Xylose Lysine Desoxylate Agar

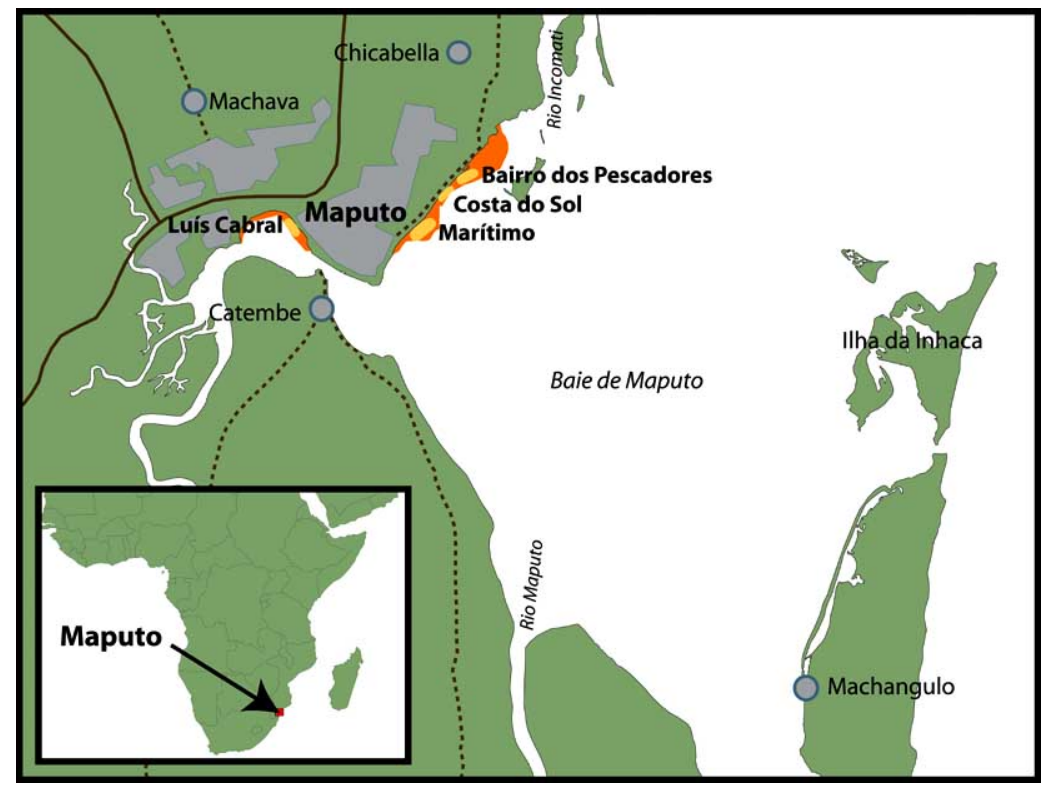

Fig. (1). Map showing Maputo, the capital of Mozambique, as well as the two sampling sites (Bairro dos Pescadores and Bairro Luis Cabral) at the outer and inner part, respectively, of Maputo Bay. 
Table 1. List of Primers (in Accordance to Publications in Reference list) that were used for the PCR Analyses of Genes Encoding Different Virulent Factors in $E$. coli Strains Isolated from Clams

\begin{tabular}{|c|c|c|c|c|}
\hline Virulence Factor (biotype) & Gene & Primer Sequence 5'-3' [ref] & Product (bp) & Annealing $\left({ }^{\circ} \mathrm{C}\right.$-sec $)$ \\
\hline Aerobactin & iutA & $\begin{array}{l}\text { GGC TGG ACA TCA TGG GAA CTG G } \\
\text { CGT CGG GAA CGG GTA GAA TCG } \\
{[39]}\end{array}$ & 301 & $65 / 60$ \\
\hline Type 1 fimbriae & FimA & $\begin{array}{l}\text { CGA CGC ATC TTC CTC ATT CTT CT } \\
\text { ATT GGT TCC GTT ATT CAG GGT TG } \\
{[21]}\end{array}$ & 721 & $65 / 60$ \\
\hline S. fimbriae & $\begin{array}{l}s f a D \\
s f a E\end{array}$ & $\begin{array}{l}\text { CTC CGG AGA ACT GGG TGC ATC TTA C } \\
\text { CGG AGG AGT AAT TAC AAA CCT GGC A } \\
{[40]}\end{array}$ & 410 & $65 / 60$ \\
\hline P. fimbriae & papC & $\begin{array}{l}\text { GAC GGC TGT ACT GCA GGG TGT GGC G } \\
\text { ATA TCC TTT CTG CAG GGA TGC AAT A } \\
{[40]}\end{array}$ & 328 & $65 / 60$ \\
\hline $\begin{array}{l}\text { Attaching and effacing, intimin } \\
\text { structural gene (EHEC, EPEC) }\end{array}$ & eaeA & $\begin{array}{l}\text { AAA CAG GTG AAA CTG TTG CC } \\
\text { CTC TGC AGA TTA ACC TCT GC } \\
{[42]}\end{array}$ & 454 & $57 / 60$ \\
\hline Shiga toxin 1 (EHEC) & $V T 1$ & $\begin{array}{l}\text { GAA GAG TCC GTG GGA TTA CG } \\
\text { AGC GAT GCA GCT ATT AAT AA } \\
{[43]}\end{array}$ & 130 & $55 / 45$ \\
\hline Shiga toxin 2 (EHEC) & $V T 2$ & $\begin{array}{l}\text { ACC GTT TTT CAG ATT } \text { TT }^{\mathrm{G}}{ }_{\text {A }} \text { CAC ATA } \\
\text { TAC ACA GGA GCA GTT TCA GAC AGT } \\
{[43]}\end{array}$ & 298 & $55 / 45$ \\
\hline Heat-stable enterotoxin (ETEC) & $S T$ & $\begin{array}{l}\text { CTG TAT TGT CTT TTT CAC CT } \\
\text { GCA CCC GGT ACA AGC AGG AT } \\
{[44]}\end{array}$ & 182 & $56 / 120$ \\
\hline $\begin{array}{l}\text { Plasmid-encoded heat-labile toxin } \\
\text { (EAggEC) }\end{array}$ & Pet & $\begin{array}{l}\text { TCA TTT CCA GCA CTT CCT GT } \\
\text { CTC CGA CAG TAT TTG CTC GT } \\
{[42]}\end{array}$ & 442 & $57 / 60$ \\
\hline Heat-stable enterotoxin (EAggEC) & astA & $\begin{array}{l}\text { GCC ATC AAC ACA GTA TAT CC } \\
\text { GAG TGA CGG CTT TGT AGT CC } \\
{[42]}\end{array}$ & 106 & $57 / 60$ \\
\hline $\begin{array}{l}\text { Transcriptional activator for ag- } \\
\text { gregative adherence fimbriae I } \\
\text { expression (EAggEC) }\end{array}$ & $\operatorname{agg} R$ & $\begin{array}{l}\text { GTA TAC ACA AAA GAA GGA AGC } \\
\text { ACA GAA TCG TCA GCA TCA GC } \\
{[45]}\end{array}$ & 254 & $57 / 60$ \\
\hline
\end{tabular}

(XLD; CM0469, Oxoid) and Triple Sugar Iron Agar (TSIA; CM 0277, Oxoid), and incubated at $37^{\circ} \mathrm{C}$ for $24 \mathrm{~h}$. Isolated Salmonella colonies were transported to the Department of Clinic Bacteriology, University of Gothenburg, Sweden (May-June 2004; n=4; full serotyping not performed) and to the Bacterological Laboratory at the Central Hospital in Kristianstad, Sweden (November 2005; n=21; full serotyping performed) for identification and antibiotic resistance tests. Putative Salmonella colonies were identified by seven tube tests (Indol, $\mathrm{H}_{2} \mathrm{~S}$, ODS, Mannitol, Urea, LDC and VP) and phage typing. Both these laboratories use the quality assurance system stated by The Swedish Board for Accreditation and Conformity Assessment. 


\section{Antibiotic Resistance}

The isolates were tested for antibiotic resistance by the disc diffusion method according to Swedish Reference Group for Antibiotics (SRGA) and its subcommittee on methodology (SRGA-M) (http://www.srga.org/ Accessed 04-09-01). Single bacterial colonies were diluted in $10 \mathrm{ml}$ sterile $0.9 \% \mathrm{NaCl}$ and spread onto specific antibiotic resistance plates (CM0471 'ISO-sensitest' agar, Oxoid) and different antibiotic test discs (Oxoid) were applied on the plates. These were incubated at $37^{\circ} \mathrm{C}$ for about $24 \mathrm{~h}$ and the size of inhibition zones was then measured and judged according to the breakpoint values $(\mathrm{mm})$ that give the criteria for antibiotic resistance, intermediate or complete sensitivity.

\section{Statistical Analyses}

The comparison between levels of E. coli (MPN per 100 $\mathrm{g}$ tissue) obtained from the different seasons was analyzed using One-way analysis of variance (ANOVA). Two-way ANOVA was used to compare differences between sites during the two seasons, after balancing the numbers of data by a random exclusion of one of the samples from Bairro Luís Cabral (Sigma Stat, version 3; Jandel Scientific Software, San Rafael, CA). The homogeneity of data and power of analyses were tested before entering the ANOVA. The numbers of virulent genes of $E$. coli that were found during the rainy and dry seasons, respectively, were compared using ttest. Significant value was set to $\mathrm{p}<0.05$.

\section{RESULTS}

\section{Total Coliforms and E. coli}

The mean log-MPN per $100 \mathrm{~g}$ tissue of total coliform bacteria analyzed during the dry season $(n=22)$ was $4.68 \pm 0.87$ and $4.18 \pm 0.89$ during the rainy season $(n=12$; $\mathrm{p}=0.161$ ). The corresponding values of thermo tolerant $E$. coli were $3.63 \pm 0.77$ and $3.96 \pm 0.83$, respectively, indicating no significant differences between seasons $(\mathrm{p}=0.328)$. Pooled data from both of the seasons showed no statistically significant differences $(\mathrm{p}=0.097)$ of $E$. coli between samples bought from the markets (mean log-MPN per $100 \mathrm{~g}$ : $3.43 \pm 0.84 ; \mathrm{n}=21$ ) and the collectors (mean log-MPN per 100 g: $3.97 \pm 0.79 ; n=13)$. The comparison between the two sampling sites, Bairro dos Pescadores (mean log-MPN per $100 \mathrm{~g}$ : $3.43 \pm 0.40 ; \mathrm{n}=6$ ) and Bairro Luís Cabral (mean log-MPN per 100 g: $4.87 \pm 0.42 ; n=6$ ), showed a significant difference (Sum of square 4.43; F 17.8; $\mathrm{p}=0.003$ ). The two-way ANOVA confirmed that the difference observed between the two sites was not depend on the season (Sum of square 0.56; $\mathrm{F} 2.25 ; \mathrm{p}=0.172$ ).
According to the Council Directive 91/492 EEC [23] the sanitary level of the collected clams exceeded the level of category A (consumption without restrictions) on every occasion. Category B and C $(<6000$ and $<60,000$ MPN coliforms per $100 \mathrm{~g}$ tissue, respectively) were each represented in $31 \%$ of the samples and the rest $(38 \%)$ were classified as contamination level of "prohibited" (>60,000 MPN coliforms per $100 \mathrm{~g}$ tissue). On two occasions there were $>500,000$ MPN coliforms per $100 \mathrm{~g}$ tissue. Other thermo tolerant coliformic species beside E. coli that were isolated and identified $(\mathrm{n}=13)$ included Klebsiella pneumoniae pneumoniae, K. ornithinolytica, K. planticola, Enterobacter cloacae and Shigella spp. In addition Acinetobacter baumannii, Flavimonas oryzihabitans, Erwinia spp. and Serratia marescens were found. Some samples, especially those from the fish markets, were heavily contaminated with Pseudomona spp.

Fifteen E. coli strains were isolated during the rainy season and $60 \%$ of these were positive for fimA. Fourteen strains were isolated during the dry season and $29 \%$ were positive for $\operatorname{fimA}$ (t-test rainy versus dry season: $\mathrm{p}=0.046$ ). Altogether $45 \%$ of the 29 samples were positive for this virulent gene. None of the isolates were positive for the other gene tested (Table 2).

\section{Salmonella spp.}

During the dry season, Salmonella spp. were found in three out of 11 samples (one analysis failed) and the bacterial growth was poor, with only a few colony-forming units on each agar plate (Fig. 2). During the rainy season, all samples $(\mathrm{n}=22)$ were positive for Salmonella spp. and showed dense growth. Samples positive for Salmonella spp. were equally distributed among sampling sites. The isolated Salmonella strains were identified as $S$. enterica serovar Typhimurium $(n=25)$. Five isolates were further verified to belong to serotype B0, four to $\mathrm{C} 2$ and two to $\mathrm{C} 1$.

\section{Antibiotic Resistance}

The isolated E. coli strains (n=29) were sensitive to most of the antibiotics tested except cefadroxil and ampicillin. Forty one $\%$ of the strains were resistant to tetracycline (Table 3). The main part of the isolated Salmonella strains $(n=17)$ was sensitive to all tested antibiotics apart from cefadroxil, which showed intermediate sensitivity. In addition, one strain was resistant and four were intermediate sensitive to ampicillin.

In general, the resistance among the other coliformic thermo tolerant strains of Enterobacteriaceae (Klebsiella

Table 2. List of Reference Strains used for the PCR Analyses of Virulent Genes in E. coli Isolates from Clams

\begin{tabular}{|l|l|l|}
\hline Category & Reference Strains & Target Gene(s) \\
\hline \hline EHEC & CCUG (DCBS 291 97) & VT1, VT2 \\
\hline EPEC & CCUG 36 068 & perA, eaeA \\
\hline ETEC & CCUG 29 197 & LT, ST \\
\hline EAggEC & CCUG 38 083 aggR, pet, astA \\
\hline E. coli & 233 & iut, FimA, sfaD, papC, hlyA \\
\hline Klebsiella pneumoniae subsp. pneumoniae & CCGU 225 T & Negative control \\
\hline
\end{tabular}



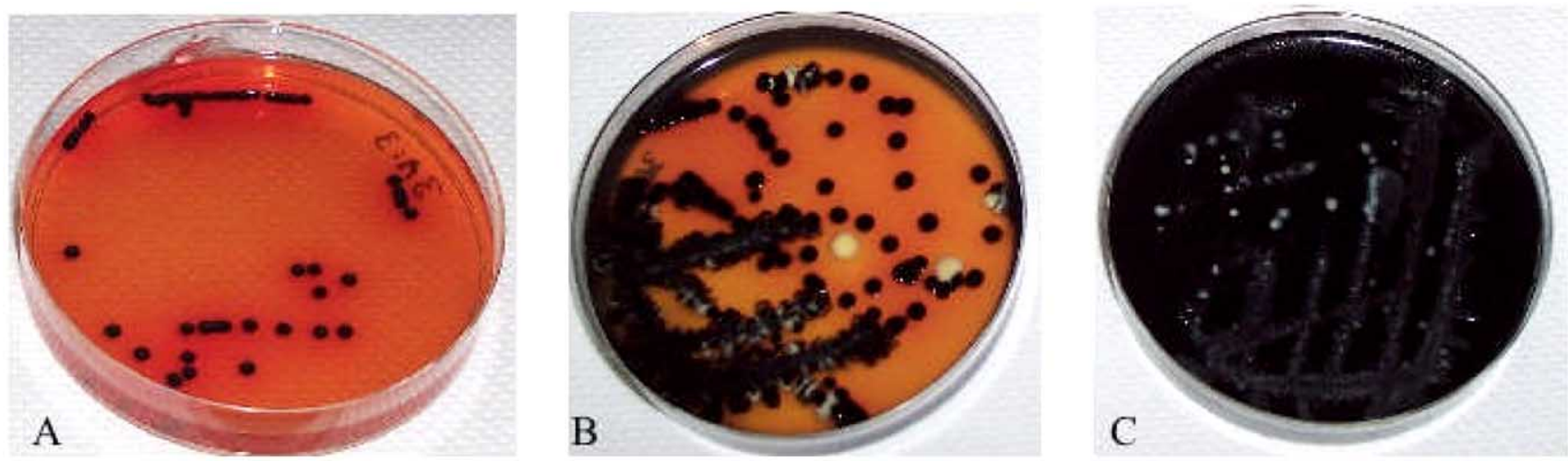

Fig. (2). The images illustrate the seasonal differences in growth density of Salmonella colonies on XLD-agar plates. Plate A shows the colony density that was representative for the Salmonella positive samples during the dry season. Plate $\mathbf{B}$ and $\mathbf{C}$ show the high density and black coloring of the agar that were commonly found during the rainy season when $100 \%$ of the samples were Salmonella positive.

Table 3. Antibiotic Resistance Tests for Isolated Strains of E. coli, Salmonella, other Coliformic Enterobacteriae (Klebsiella spp. E. cloacae and Shigella spp.), and Coliformic Non- Enterobacteriae (Others: A. baumannii, F. oryzihabitans, Erwinia spp. and $S$. marescens). The Results are Presented as Numbers of Analysed Strains Judged as S: Sensitivity; I: Intermediate Sensitivity; R: Resistance, respectively

\begin{tabular}{|c|c|c|c|c|c|c|c|c|c|c|c|c|}
\hline Antibiotics Tested & \multicolumn{3}{|c|}{ E. $\operatorname{coli}(\mathrm{n}=29)$} & \multicolumn{3}{|c|}{ Salmonella $(\mathrm{n}=22)$} & \multicolumn{3}{|c|}{ Other Coliformic $(n=13)$} & \multicolumn{3}{|c|}{ Others $(n=7)$} \\
\hline Mecillinam & 27 & 2 & 0 & 22 & 0 & 0 & 11 & 2 & 0 & 2 & 5 & 0 \\
\hline Ampicillin & 0 & 27 & 2 & 17 & 4 & 1 & 0 & 6 & 7 & 0 & 6 & 1 \\
\hline Ceftazidime & 29 & 6 & 0 & 22 & 0 & 0 & 10 & 2 & 1 & 2 & 0 & 5 \\
\hline Tobramycin & 29 & 0 & 0 & 22 & 0 & 0 & 12 & 0 & 1 & 7 & 0 & 0 \\
\hline Chloramphenicol & 27 & 2 & 0 & 22 & 0 & 0 & 11 & 0 & 2 & 2 & 0 & 5 \\
\hline Ciprofloxacin & 27 & 2 & 0 & 22 & 0 & 0 & 13 & 0 & 0 & 7 & 0 & 0 \\
\hline Norafloxacin & 29 & 0 & 0 & 22 & 0 & 0 & 13 & 0 & 0 & 7 & 0 & 0 \\
\hline Gentamycin & 29 & 0 & 0 & $17 *$ & 0 & 0 & 13 & 0 & 0 & 7 & 0 & 0 \\
\hline Nalidixic acid & N.T & N.T & N.T & $17^{*}$ & 0 & 0 & N.T & N.T & N.T & N.T & N.T & N.T \\
\hline Cephuroxime & N.T & N.T & N.T & $17 *$ & 0 & 0 & N.T & N.T & N.T & N.T & N.T & N.T \\
\hline Trimethoprimsulfa & N.T & N.T & N.T & $17 *$ & 0 & 0 & N.T & N.T & N.T & N.T & N.T & N.T \\
\hline
\end{tabular}

$*_{\mathrm{n}=17}$; N.T.: Not tested.

spp., Enterobacter spp., Shigella spp. Erwinia spp. and $S$. marescens) and non-Enterobacteriaceae (Acinetobacter baumannii and Flavomonas oryzihabitans) were more pronounced. The Shigella isolate showed resistance against cefadroxil, chloramphenicol, nitrofurantoin, ceftazidime and tetracycline, and intermediate sensitivity to ampicillin, trimethoprim and mecillinam.

\section{DISCUSSION}

This study showed high levels of fecal contamination in bivalves used for consumption in the area of Maputo city,
Mozambique. There is a lack of directive for sanitary safety of bivalves in the country where only exported shellfish such as lobsters are controlled. However, in accordance to the Consul Directive 91/492 [23] that has been practiced within the European Union all samples exceeded the limit for consumption without restrictions (<300 MPN fecal coliforms per $100 \mathrm{~g}$ tissue). Almost $40 \%$ of the samples fell into the category "prohibited for human consumption" and the rest of the samples were classified as category B or C, which demands depuration before consumption.

The sites chosen for collecting the clams appear to reflect a gradient of contamination, with highest levels of $E$. coli in 
the inner part of the bay where the population of Maputo is more concentrated. In contrast to Salmonella the occurrence of $E$. coli was seemingly independent of season. Our results showed $100 \%$ prevalence of Salmonella in the analyzed clam samples from the rainy season but only in $30 \%$ of the samples from the dry season. Although the analyses of Salmonella were not quantitative, it was noticeable by comparing the growth density after enrichment that the clams contained higher numbers of this bacterium during the warmer, rainy season. This was in agreement with what has been reported by Haley et al. [24] from southern Georgia, USA. They found that the increase of Salmonella in aquatic environment coincided with both higher temperatures and the rainy season. Another study, committed on more than 5000 Salmonella strains [25] isolated from live bivalves in Spain, identified $15 \%$ as $S$. enterica serovar Typhimurium. In contrast to the other strains these were found only during warmer periods.

The mean value of precipitation in Maputo during November 2005 was $76.6 \mathrm{~mm}$ but only $18.5 \mathrm{~mm}$ in May and $24.6 \mathrm{~mm}$ in June 2004 (data obtained from The National Institute of Metrology, Maputo, Mozambique). Most probably the transport of fecal contaminants to seawater increases during events of high land run-off $[26,27]$. Such events may also increase the turbidity of the shallow Maputo Bay which probably inhibits the bacterial inactivating mechanism of solar radiation as has been shown in studies performed in other areas [28, 29]. The mean water temperature of Maputo Bay rises from $19-20^{\circ} \mathrm{C}$ during the dry season to $26-28^{\circ} \mathrm{C}$ during the rainy season [19]. A previous study by [30] showed that growth of virulent strains of $S$. enterica serovar Typhimurium, inoculated in boreal adapted blue mussels (Mytilus edulis), were favored by water temperature of $20^{\circ} \mathrm{C}$ compared to that of $6^{\circ} \mathrm{C}$. At the higher temperature the bacteria multiplied with lethal effects on the mussels. Temperature should also be considered during storage of the clams at the fish markets in Maputo where no cooling facilities are available. Pseudomonas spp. was often detected in clams from these markets, indicating spoilage of the clam tissue. Beside the effects of the quality of taste, smell and dietary value, high temperature storage may also increase the numbers of pathogenic bacteria. Other environmental properties related to the rainy seasons, like increased level of dissolved organic nutrients and decrease in salinity, may also favor the viability of the bacteria.

Clinical tests have shown an increase of $E$. coli isolates from hospitalized children during the rainy season, which indicates higher virulence of $E$. coli [31]. Also in clams the virulence of $E$. coli was seemingly more pronounced during the rainy season when twice as many of the isolates were positive for the fimA gene compared to isolates from the dry season. This gene product is a virulence indicator as it is essential for $E$. coli adherence to intestinal epithelial cells. On the other hand, the positive isolates were negative for other tested virulence genes which indicates that they are not able to cause hemolytic diarrheal disease. Among the other isolated coliformic Enterobacteriaceae, Shigella sp. was identified even though we did not use any selective methodology [32] to trace it. This observation is of great concern since Shigella even in low doses can cause severe gastrointestinal infection through seafood consumption [33] and it points out the need for further investigations. This is also the case for the highly virulent $S$. typhi, which may occur in clams but might have been overlooked due to the methodology used in this study. Nevertheless, the frequent findings of $S$. enterica serovar Typhimurium should be considered since it constitute a threat for public health as it is known to cause non-typhoid prolonged gastroenteritis, particularly common among the pediatric population [34].

In general, the antibiotic resistance found in this study was not as pronounced as reported from Europe [35]. However, strains of both E. coli and Salmonella showed rather prominent resistance against the $B$-lactams, cefadroxil and ampillicin. This pattern is alarming due to the fact that ampicillin is the main treatment of infectious diarrhea for children under two years of age in rural districts of the Maputo region [31]. Less than $30 \%$ of the total isolates from clams were sensitive to ampicillin. Tetracycline was also among the notable antibiotics. Several of the isolated $E$. coli strains $(41 \%)$ as well as the Shigella isolate showed resistance to this inexpensive and widely distributed antibiotic. Resistance to tetracycline has been recognized in many pathogens and commensal bacteria in developed countries and this was also experienced during previous cholera outbreaks in Mozambique, South Africa and Madagascar [36, 37]. According to registration protocols for utilization of antibiotics, kindly provided by The Section of Laboratory, Health Ministry, Maputo, tetracycline is one of the most common antibiotic treatments for human infections. Another antibiotic within this group, the oxitertracycline, is also commonly distributed as used by farmers in the Maputo district for treatment of rickettsia-infected cattle (Pers. Comm. Dr. L. Neves, The Veterinary Institute, Maputo, Mozambique). The antimicrobials most widely regarded as optimal for treatment of salmonellosis in adults are fluoroquinolones [38] and it was satisfying that our results, in agreement with a study of Salmonella from children with bacteraemia in Kenya [34], showed high sensitivity to ciprofloxacin. Antibiotic resistance may comprise an increasing threat as these drugs are frequently misused and unregulated available in pharmacies or general stores in Maputo.

\section{CONCLUSIONS}

Most of the strains of $E$. coli that were found in the clams from Maputo were seemingly quite harmless. However, the high numbers of coliforms certainly indicated a local and continuous source of fecal contamination with hazardous potential, such as the high prevalence of Salmonella and the observed multi-resistant Shigella. There might also be more distant sources of pathogens like the recent introduction of more intense livestock in catchments upstream the rivers that enter Maputo Bay. Such a contribution of enteric bacteria may also increase the spreading of antibiotic resistance since antibiotics are commonly used for infection treatments of cattle.

When pathogens accumulate in clams they constitute a particular risk since clams are consumed only lightly cooked to retain the palatable texture and nutritional value. Indeed the results of this initial study indicated a potential risk of consuming clams from Maputo Bay but further studies are needed in order to predict seasonal peaks or epidemic outbreaks of enteric infections, and thereby offer opportunities for mitigation, and even prevention of these kinds of dis- 
eases. This is of increasing importance for the growing population of the area, particularly children and for the increasing numbers of immunocompromised individuals, like HIVinfected persons, who are more susceptible to infections. It is also of great importance for the growing tourism which can be of major economic importance.

\section{ACKNOWLEDGEMENTS}

This study was supported by the research grant SWE2003-108 and SWE-2005-397 from the Swedish International Development Cooperation Agency (SIDA). We thank the Biology Department at University Eduardo Mondlane, Maputo, Mozambique for hospitality and use of facilities at the institute.

\section{REFERENCES}

[1] Sockett PN, West PA, Jacob M. Shellfish and public health. PHLS Microbiol Digest 1985; 2: 29-35.

[2] Rippey SR. Infectious diseases associated with molluscan shellfish consumption. Clin Microbiol Rev 1994; 7: 419-25.

[3] Potasman I, Paz A, Odeh M. Infectious outbreaks associated with bivalve shellfish consumption: a world wide perspective. Clin Infect Dis 2002; 35: 921-8.

[4] Siegfried WR, Hockey PAR, Branch GM. The exploitation of intertidal and subtidal biotic resources of rocky shores in Chile and in South Africa - An overview. In: Siegfried WR, Ed. Rocky Shores: Exploitation in Chile and South Africa. Springer Verlag: Berlin 1994: 1-15.

[5] De Boer WF, Blijdenstein AF, Longamane F. Prey choice and habitat use of people exploiting intertidal resources. Environ Conserv 2002; 29: 238-52.

[6] Fernandes Â, Murta M, Manuel A, Amado I, Abixai Z. Pollution in Maputo Bay. Rev Méd Moçam 1993; 4: 2.

[7] Nenonen N, Hernroth B, Chauque A, Hannoun C, Bergström T. Detection of Hepatitis A virus genotype IB variants in clams from Maputo Bay, Mozambique. J Med Virol 2006; 78: 896-905.

[8] Kosek M, Bern C, Guerrant RL. The global burden of diarrhoeal disease, as estimated from studies published between 1992 and 2000. Bull World Health Organ 2003; 81: 197-204.

[9] Dgedge M, Novoa A, Macassa G, et al. The burden of disease in Maputo City, Mozambique: registered and autopsied death in 1994. Bull World Health Organ 2001; 79: 546-52.

[10] Black RE. Epidemiology of travelers' diarrhea and relative importance of various pathogens. Rev Infect Dis 1990; 12: 73-9.

[11] Lima AA. Tropical diarrhoea: new developments in traveller's diarrhoea. Curr Opin Infect Dis 2001; 14: 547-52.

[12] Bölin I, Wiklund G, Qadri F, et al. Enterotoxigenic Escherichia coli with STh and STp genotypes is associated with diarrhea both in children in areas of endemicity and in travellers. J Clin Microbiol 2006; 44: 3872-7.

[13] Crane JK, Choudhari SS, Naeher TM, Duffey ME. Mutual enhancement of virulence by enterotoxigenic and enteropathogenic Escherichia coli. Infect Immun 2006; 74: 1505-15.

[14] Galanis E, Lo Fo Wong DM, Patrick ME, et al. Global Salm-Surv. Web-based surveillance and global Salmonella distribution, 20002002. Emerg Infect Dis 2006; 12: 381-8.

[15] Wilson IG, Moore JE. Presence of Salmonella spp. and Campylobacter spp. in shellfish. Epidemiol Infect 1996; 116: 147- 53.

[16] Hatha AAM, Lakshmanaperumalsamy P. Prevalence of Salmonella in fish and crustaceans from markets in Coimbatore, South India. Food Microbiol 1997; 14: 111-6.

[17] Heinitz ML, Ruble RD, Wagner DE, Tatini SR. Incidence of Salmonella in fish and seafood. J Food Prot 2000; 63: 579-592.

[18] Kariuki S, Revathi G, Kariuki N, et al. Invasive multidrug-resistant non-typhoidal Salmonella infections in Africa: Zoonotic or anthroponotic transmission? J Med Microbiol 2006; 55: 585-91.

[19] Saide FVM. Tides, circulation and water masses in Maputo Bay. Ph.D-thesis. Department Oceanography, Goteborg University, Goteborg: Sweden 2000.

[20] Donovan TJ, Gallacher S, Andrews NJ, et al. Modification of the standard method used in the United Kingdom for counting Escherichia coli in live bivalve molluscs. Com Dis Pub Health 1998; 1: 188-96.
[21] Nowrouzian F. Colonization, persistence and virulence factors in Escherichia coli strains in the human intestinal microflora. Ph.D. thesis. Dept. Clin. Bact., Goteborg University, Goteborg: Sweden 2002.

[22] Anonymous. NMKL - Nordic Committee on Food Analysis method No. 71, 5 ed.: Salmonella Detection in foods. Elaborated by Wiberg C, National Food Administration, SE-751 26 Uppsala Sweden c/o National Veterinary Institute, Dept. N-0033 Oslo 1999. Anonymous. Council Directive of 15 July laying down the health conditions for the production and the placing on the market of live bivalve mollusks (91/492/EEC). Off J Eur Commun 1991; L268: 113.

[24] Haley B, Cole D, Lipp EK. Impact of climate and weather on Salmonella densities in the aquatic environment. EOS Trans. Am Geophys Union 2006; 87 (36): Suppl. Abstract OS25M-07.

[25] Martinez-Urtaza J, Saco M, de Novoa J, et al. Influence of environmental factors and human activity on the presence of Salmonella serovars in marine environment. Appl Environ Microbiol 2004; 70: 2089-97.

[26] Baudart J, Grabulos J, Baresseau JP, Lebaron P. Salmonella spp. and fecal coliform loads in costal waters from a point $v s$. non-point source of pollution. J Environ Qual 2000; 29: 241-50.

[27] Hernroth BE, Hansson-Conden AC, Rehnstam-Holm AS, Girones R, Allard AK. Environmental factors influencing human viral pathogens and their potential indicator organisms in the blue mussel, Mytilus edulis: first Scandinavian report. Appl Environ Microbiol 2002; 68: 4523-33.

[28] Sinton LW, Finlay RK, Lynch PA. Sunlight inactivation of feacal bacteriophages and bacteria in sewage polluted seawater. Appl Environ Microbiol 1999; 65: 3605-13.

[29] Chandran A, Mohamed Hatha AA. Relative survival of Escherichia coli and Salmonella typhimurium in a tropical estuary. Water Res 2005; 39: 1397-403.

[30] Hernroth B. Factors influencing bactericidal activity of blue mussel (Mytilus edulis) haemocytes against Salmonella typhimurium. Fish Shellfish Immunol 2003; 14: 93-104.

[31] Mandomando IM, Macete EV, Ruiz J, et al. Etiology of diarrhea in children younger than 5 years of age admitted in a rural hospital of southern Mozambique. Am J Trop Med Hyg 2007; 76: 522-27.

[32] Warren BR, Parish ME, Schneider KR. Shigella as a food borne pathogen and current methods for detection in food. Crit Rev Food Sci Nutr 2006; 46: 551-67.

[33] Feldhusen F. The role of seafood in bacterial foodborne diseases. Microbes Infect 2000; 2: 1651-60.

[34] Kariuki S, Revathi G, Kiiru J, Lowe B, Berkley JA, Hart CA Decreasing prevalence of antimicrobial resistance in non-typhoidal Salmonella isolated from children with bacteraemia in a rural district hospital, Kenya. Int J Antimicrob Agents 2006; 28: 166-71.

[35] Mayor S. Antibiotic resistance is highest in south and east Europe. BMJ 2005; 330: 383.

[36] Duncan S, Glover LA, Killham K, Prosser JI. Luminescence-based detection of activity both of starved and viable but nonculturable bacteria. Appl Environ Microbiol 1994; 60: 1308-16.

[37] Dalsgaard A, Forslund A, Tam NV, Vinh DX, Cam PD. Cholera in Vietnam: Changes in genotypes and emergence of class I integrons containing aminoglycosidase resistance gene cassettes in Vibrio cholerae O1 strains isolated from 1979 to 1996. J Clin Microbiol 1999; 37: 734-41.

[38] Hohmann EL. Nontyphoidal salmonellosis. Clin Infect Dis 2001; 32: 263-9.

[39] Johnson JR, Stapleton AE, Russo TA, Scheutz F, Brown JJ, Maslow JN. Characteristics and prevalence within serogroup O4 of a J96-like clonal group of uropathogenic Escherichia coli O4:H5 containing the class I and class II alleles of papG. Infect Immun 1997; 65: 2153-9.

[40] Le Bouguenec C, Archambaud M, Labinge A. Rapid and specific detection of the pap, afa and sfa adhesinencoding operons in uropathogenic Escherichia coli strains by polymerase chain reaction. J Clin Microbiol 1992; 30: 1189-93.

[41] Yamamoto S, Terai A, Yuri K, Kurazono H, Takeda Y, Yoshida O Detection of urovirulence factors in Escherichia coli by multiplex polymerase chain reaction. FEMS Immunol Med Microbiol 1995; 12: 85-90.

[42] Yatsuyanagi J, Saito S, Sato H, Miyajima Y, Amano K-I, Enomoto SK. Characterization of Enteropathogenic and enteroaggregative 
Escherichia coli Isolated from Diarrheal Outbreaks. J Clin Microbiol 2002; 40: 294-7.

[43] Nguyen TV, Van PL, Huy CH, Gia KN, Weintraub A. Detection and characterization of diarrheagenic Escherichia coli from young children in Hanoi, Vietnam. J Clin Microbiol 2005; 43: 755-60.

[44] Tornieporth NG, John J, Salgado K, et al. Differention of pathogenic Escherichia coli strains in Brazilian children by PCR. J Clin Microbiol 1995; 33: 1371-4.
[45]

Ratchtrachenchai OA, Subpasu S, Ito K. Investigation on enteroaggregative Escherichia coli infection by multiplex PCR. Bull Dept Med Sci 1997; 39: 211-20.

(c) Collin et al.; Licensee Bentham Open.

This is an open access article licensed under the terms of the Creative Commons Attribution Non-Commercial License (http://creativecommons.org/licenses/by-nc/3.0/) which permits unrestricted, non-commercial use, distribution and reproduction in any medium, provided the work is properly cited. 